\title{
Metabolic Effect of 3,3',5'-Triiodothyronine in Cultured Growth Hormone-producing Rat Pituitary Tumor Cells

\author{
Evidence for a Unique Mechanism of Thyroid Hormone Action
}

Donald L. St. Germain

Departments of Medicine and Physiology, Dartmouth Medical School, Hanover, New Hampshire 03756

\begin{abstract}
Physiologic levels of $3,3^{\prime}, 5^{\prime}$-triiodothyronine $\left(\mathbf{r T}_{3}\right)$ are generally believed to have minimal metabolic effects in the pituitary gland and other tissues. In the present studies, the regulatory role of $\mathrm{rT}_{3}$ and other thyroid hormones on iodothyronine $5^{\prime}$ deiodinase (I5'D) activity was studied in a growth hormoneproducing rat pituitary tumor cell line ( $\mathrm{GH}_{3}$ cells). I5'D activity was thiol-dependent and displayed nonlinear reaction kinetics suggesting the presence of two enzymatic processes, one having a low Michaelis constant $\left(K_{m}\right.$ for thyroxine $\left[T_{4}\right]$ of $2 \mathrm{nM}$ ) and a second with a high $K_{\mathrm{m}}$ value $(0.9 \mu \mathrm{M})$. Growth of cells in hormone-depleted medium resulted in a two- to 3.5-fold increase in low $K_{\mathrm{m}} \mathrm{I5}^{\prime} \mathrm{D}$ activity $(P<0.001)$. The addition of thyroid hormones to the culture medium resulted in a rapid, dosedependent inhibition of low $K_{\mathrm{m}}$ I5'D activity with the following order of analogue potency: $r T_{3} \geq T_{4}>3,5,3^{\prime}$-triiodothyronine $\left(T_{3}\right)$. Using serum-free culture conditions, $r T_{3}$ was $\sim 50$ times more active than $T_{3}$. These inhibitory effects were noted within $15 \mathrm{~min}$ of hormone addition and could not be attributed to substrate competition with $T_{4}$. These findings suggest that the control of $T_{4}$ to $T_{3}$ conversion by thyroid hormones in the anterior pituitary gland is mediated by a unique cellular mechanism that is independent of the nuclear $T_{3}$ receptor; and under some circumstances, $\mathbf{r T}_{3}$ may play a regulatory role in controlling this enzymatic process.
\end{abstract}

\section{Introduction}

The metabolic actions of thyroid hormones appear to be mediated primarily through the interaction of 3,5,3'-triiodothyronine $\left(\mathrm{T}_{3}\right)^{1}$ with specific nuclear receptors (1). In the various growth hormone-producing rat pituitary tumor cell

Portions of this work were presented at the 60th meeting of the American Thyroid Association, New York, September 1984.

Address correspondence to Dr. St. Germain, Division of Endocrinology, Dartmouth Medical School, Hanover, NH 03756.

Received for publication 28 February 1985.

1. Abbreviations used in this paper: DTT, dithiothreitol; FCS, fetal calf serum; GH cells, growth hormone-producing cell lines; HS, horse serum; I5'D, iodothyronine 5'-deiodinase; $K_{\mathrm{m}}$, Michaelis constant; $\mathrm{rT}_{3}$, 3,3',5'-triiodothyronine; $T_{3}, 3,5,3^{\prime}$-triiodothyronine; $T_{4}$, thyroxine.

J. Clin. Invest.

(c) The American Society for Clinical Investigation, Inc.

0021-9738/85/08/0890/04 \$1.00

Volume 76, August 1985, 890-893 lines ( $\mathrm{GH}$ cells) for example, $\mathrm{T}_{3}$ is the most potent thyroid hormone analogue in stimulating glucose consumption (2), growth hormone production (3), and amino acid transport (4), and these effects correlate well with the proportion of nuclear binding sites occupied by $\mathrm{T}_{3}$. Although 3,3',5'-triiodothyronine $\left(\mathrm{rT}_{3}\right)$ also has agonist activity in $\mathrm{GH}$ cells, 1,000-fold greater concentrations are required, presumably due to the nuclear receptor having a significantly lower affinity for $\mathrm{rT}_{3}$ (5). In other systems, the metabolic effects of $\mathrm{rT}_{3}$ also appear to be minimal (5).

In the present studies, we used the $\mathrm{GH}_{3}$ cell line to investigate the regulatory effects of thyroid hormones on a low Michaelis constant $\left(K_{\mathrm{m}}\right)$ iodothyronine $5^{\prime}$-deiodinase (I5'D) process (type II). Our finding that $\mathrm{rT}_{3}$ is a potent and rapid inhibitor of this enzymatic process suggests that thyroid hormone control of $T_{3}$ formation in anterior pituitary tissue is mediated through a unique cellular mechanism that is independent of the nuclear $T_{3}$ receptor.

\section{Methods}

$\mathrm{GH}_{3}$ cells were obtained from the American Type Culture Collection (Rockville, MD) and were routinely grown in $75-\mathrm{cm}^{2}$ plastic flasks and 100-mm plastic culture dishes using Ham's F-10 culture medium supplemented with $2.5 \%$ fetal calf serum (FCS), $15 \%$ horse serum (HS), and gentamycin $(50 \mu \mathrm{g} / \mathrm{ml})$ in a humidified atmosphere of $5 \%$ $\mathrm{CO}_{2} / 95 \%$ air. Medium was routinely changed twice weekly. In some experiments cells were grown to near confluence in standard medium and then transferred and maintained for $4 \mathrm{~d}$ in serum-free Ham's F10 or in Ham's F-10 supplemented with FCS (10\%) that previously had been treated with either charcoal (6) or an ion exchange resin (7). According to the manufacturer's (HyClone Laboratories, Logan, UT) specifications, the $T_{4}$ and $T_{3}$ levels were $12.7 \mu \mathrm{g} / \mathrm{dl}$ and $118 \mathrm{ng} / \mathrm{dl}$, respectively, in the FCS and $2.9 \mu \mathrm{g} / \mathrm{dl}$ and $47 \mathrm{ng} / \mathrm{dl}$, respectively, in the HS. Treatment of FCS either with charcoal or with an ion exchange resin was demonstrated to remove $>99 \%$ of the iodothyronines.

Experiments were performed with cells at the near confluent stage of growth and $48 \mathrm{~h}$ after the last medium change. Cells were harvested by scraping with a rubber policeman, washed twice with ice-cold buffer (0.25 $\mathrm{M}$ sucrose, $0.02 \mathrm{M}$ Tris- $\mathrm{HCl}, \mathrm{pH} 7.6,1 \mathrm{mM} \mathrm{MgCl}_{2}, 2 \mathrm{mM}$ $\mathrm{CaCl}_{2}, 0.1 \mathrm{mM}$ dithiothreitol [DTT], 5\% glycerol), then resuspended in the same buffer and sonicated using a sonic dismembrator (Artek Systems Corp., Farmingdale, NY) for $25 \mathrm{~s}$ at a setting of 45 . The sonicate was centrifuged at $800 \mathrm{~g}$ for $10 \mathrm{~min}$ and the supernatant was used immediately for determination of $I^{\prime} \mathrm{D}$ activity as previously described $(8,9)$. $T_{3}$ production rates were quantified by radioimmunoassay (RIA) using stable thyroxine $\left(T_{4}\right)$ as a substrate at concentrations of $0.002-3.0 \mu \mathrm{M}$ in the presence of added DTT. The $\mathrm{T}_{4}$ content of the supernatant fraction, before the addition of stable $T_{4}$ or enrichment with DTT, was determined by RIA in ethanol extracts (8). Protein concentration was determined by the method of Lowry et al. (10). 
Several experiments were performed to characterize and define the optimal conditions for quantifying I5'D activity in $\mathrm{GH}_{3}$ cells: (a) enzyme activity in supernatants was found to be a linear function of both protein concentration (up to $11 \mathrm{mg} / \mathrm{ml}$ ) and incubation time (up to $45 \mathrm{~min}$ ) and was dependent on the presence of sulfhydryl reducing agents (maximum activity at $20 \mathrm{mM}$ DTT). (b) No $\mathrm{T}_{3}$ formation was noted in supernatants heated to $80^{\circ} \mathrm{C}$ for $45 \mathrm{~min}$ before incubation with $\mathrm{T}_{4}$ and DTT. (c) Incubation of supernatants with known concentrations of stable $T_{3}$ (at $37^{\circ} \mathrm{C}$ for $45 \mathrm{~min}$ in the presence of $20 \mathrm{mM}$ DTT) failed to disclose any evidence of $T_{3}$ degradation. (d) Enzyme activity determined $1-4 \mathrm{~d}$ after a medium change varied by $<15 \%$ and was the same during either the log or near confluent stages of growth.

The uptake of $\mathrm{rT}_{3}$ by $\mathrm{GH}_{3}$ cells was determined by incubating cells in medium containing a known specific activity of ${ }^{125} \mathrm{I}-\mathrm{r} \mathrm{T}_{3}$ (New England Nuclear, Boston, MA). Cells were then harvested, washed, and sonicated as above, and the amount of radioactivity in the supernate fraction was determined. The $\mathrm{rT}_{3}$ content was calculated after correcting for the proportion of counts due to ${ }^{125} \mathrm{I}$ as determined by electrophoresis (11). Stable $\mathrm{rT}_{3}$ was obtained from CalbiochemBehring Corp., La Jolla, CA.

Kinetic data were analyzed using Eadie-Hofstee plots, and nonlinear plots were resolved into two components as previously described (9). Statistical comparison was performed using the unpaired $t$ test. All results are given as mean $\pm \mathrm{SE}$.

\section{Results}

I5'D activity in $\mathrm{GH}_{3}$ cell supernatants demonstrated nonlinear reaction kinetics suggesting the presence of two enzymatic processes having $K_{\mathrm{m}}$ values of $2.4 \pm 1.0 \mathrm{nM}$ ( $n=4$ experiments) and $0.9 \pm 0.3 \mu \mathrm{M}$ (Fig. 1). Corresponding values for the maximum velocity were $23 \pm 7 \mathrm{fmol} \mathrm{T}_{3} / \mathrm{min} \mathrm{mg}$ protein and $32 \pm 6$ fmol $\mathrm{T}_{3} / \mathrm{min} \mathrm{mg}$ protein. The addition of $0.5 \mathrm{mM} 6-n$-propyl2-thiouracil to cell sonicates (in the presence of $5 \mathrm{mM}$ DTT) inhibited $\mathrm{T}_{3}$ production by $<10 \%$ at low substrate concentrations $\left(10 \mathrm{nM} \mathrm{T}_{4}\right)$ but by $53 \%(P<0.001)$ at $\mathrm{T}_{4}$ concentrations of $3 \mu \mathrm{M}$ (data not shown). In subsequent experiments I5'D activity was determined using supernatant substrate concentrations of 10 or $50 \mathrm{nM} \mathrm{T}$ and $20 \mathrm{mM}$ DTT; these conditions permit quantification of primarily the low $K_{\mathrm{m}}$ process.

The effect on I5'D activity of culturing cells in medium supplemented with different serum preparations is shown in Fig. 2. Cells grown in Ham's F-10 medium supplemented with $10 \%$ FCS manifested only $46 \%$ of the activity noted in cells cultured in standard medium. However, cells maintained in serum-free medium or in the presence of $10 \%$ resin-treated or

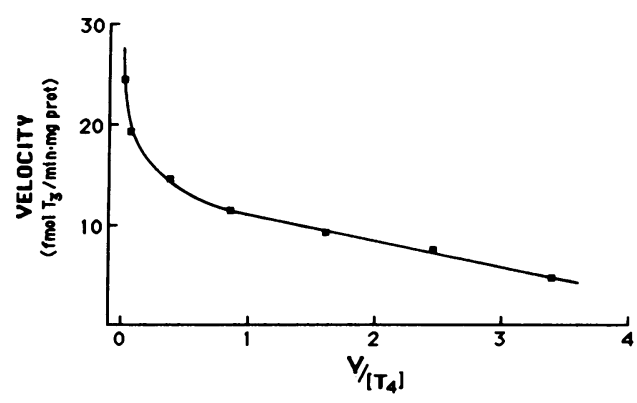

Figure 1. Kinetic analysis, utilizing an Eadie-Hofstee plot, of I5'D activity in $\mathrm{GH}_{3}$ cells. Cells were cultured in standard medium containing $2.5 \%$ FCS and $15 \%$ HS. Enzyme activity was determined using $\mathrm{T}_{4}$ concentrations of $0.002-1.0 \mu \mathrm{M}$ and $20 \mathrm{mM}$ DTT. $\mathrm{T}_{4}$ concentrations on the abscissa are expressed in nanomoles per liter. Points represent the mean of duplicate values, which differed $<15 \%$. Prot, protein.

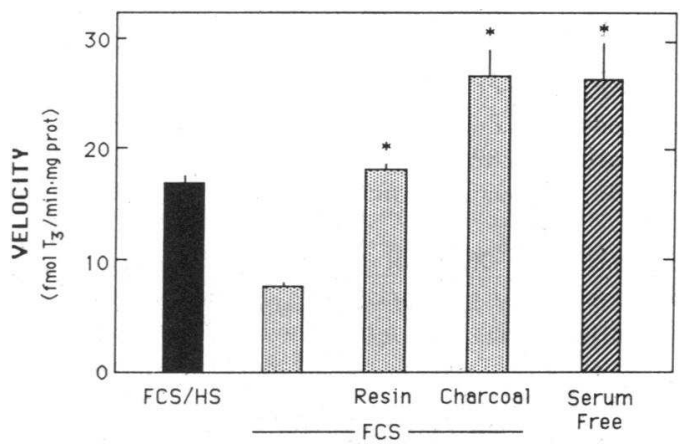

Figure 2. The effect of different medium conditions on I5'D activity in $\mathrm{GH}_{3}$ cells. Cells were grown to near confluence in standard medium (FCS/HS) and then transferred and maintained for four additional days in the medium indicated. I5' activity was determined using a $\mathrm{T}_{4}$ concentration of $10 \mathrm{nM}$ and $20 \mathrm{mM}$ DTT. Values represent the mean $\pm \mathrm{SE}$ of triplicate determinations. *, $P<0.001$ compared with cells maintained in untreated FCS. Prot, protein.

charcoal-treated FCS showed a two- to 3.5-fold increase in I5'D activity, suggesting that one or more components of serum exerted inhibitory effects on enzyme activity. The addition of $\mathrm{T}_{4}, \mathrm{~T}_{3}$, or $\mathrm{rT}_{3}$ to the culture medium resulted in significant inhibitory effects on $\mathrm{IJ}^{\prime} \mathrm{D}$ activity. Dose response curves, as determined in serum-free medium, are shown in Fig. 3. In this experiment, $\mathrm{rT}_{3}$ was somewhat more active than $\mathrm{T}_{4}$ and 50 times more active than $\mathrm{T}_{3}$ in inhibiting I5' $^{\prime} \mathrm{D}$ activity. Additional experiments $(n=5)$ using both serum-free conditions and medium supplemented with resin-treated FCS confirmed that the order of potency of these analogues was $r T_{3} \geq T_{4}$ $>T_{3}$. In medium supplemented with resin-treated FCS, $T_{3}$ concentrations of $>10^{-9} \mathrm{M}$ were required to inhibit I5' $^{\prime} \mathrm{D}$ activity. Thyronine, at concentrations up to $10^{-7} \mathrm{M}$, inhibited this process by $<10 \%$.

The potential of $\mathrm{rT}_{3}$ acting as a competitive substrate with $\mathrm{T}_{4}$ in the reaction mixture was assessed by determining the rate of $T_{3}$ formation in the presence of both added $T_{4}$ (50 $\mathrm{nM}$ ) and $\mathrm{rT}_{3}$. Concentrations of $\mathrm{rT}_{3}$ of up to $10 \mathrm{nM}$ had no effect on $T_{3}$ production rates. Quantitation of $\mathrm{rT}_{3}$ cellular uptake revealed that $4 \mathrm{~h}$ after the addition of $10^{-8} \mathrm{M} \mathrm{rT}_{3}$ to the culture medium, supernatant concentrations of $\mathrm{rT}_{3}$ were $\sim 5 \mathrm{nM}$ in cells grown in serum-free medium and $0.4 \mathrm{nM}$ in cells maintained in medium supplemented with resin-treated FCS. Thus, even at high medium $\mathrm{rT}_{3}$ concentrations, the supernatant concentrations of $\mathrm{rT}_{3}$ were insufficient to affect $\mathrm{T}_{3}$ production rates when $50 \mathrm{nM} \mathrm{T} \mathrm{T}_{4}$ was provided as substrate in the reaction mixture. Furthermore, the concentration of $T_{4}$ (as determined by RIA) in supernatants derived from cells grown in medium supplemented with resin-treated FCS and either $10^{-8} \mathrm{M}$ or $10^{-7} \mathrm{M} \mathrm{T}_{4}$ were $0.7 \mathrm{nM}$ and $7 \mathrm{nM}$, respectively; concentrations that would not add significantly to the rates of $\mathrm{T}_{3}$ formation in the reaction mixture. ${ }^{2}$

2. Based on the measured sonicate protein concentration and the known values of protein content and cellular volume of GH cells (12), the actual intracellular concentrations of $\mathrm{rT}_{3}$ and $\mathrm{T}_{4}$ can be calculated. For cells incubated for $4 \mathrm{~h}$ in medium containing $10 \% \mathrm{FCS}$, intracellular $\mathrm{rT}_{3}$ and $\mathrm{T}_{4}$ concentrations were equal to the total medium concentrations of these iodothyronines. Under serum-free medium conditions, the intracellular concentrations were $\sim 30$-fold greater than the medium concentrations. 


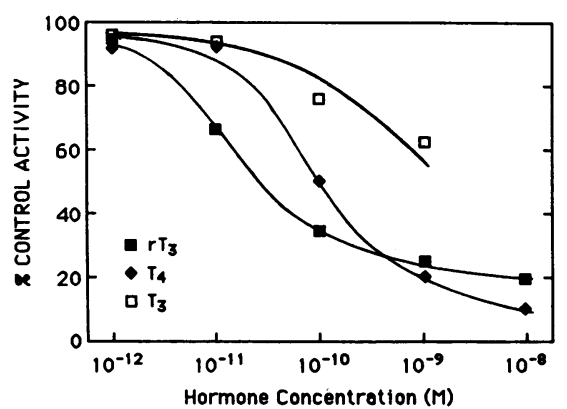

Figure 3. Dose response curves of the inhibitory effects of thyroid hormones on I5'D activity in $\mathbf{G H}_{3}$ cells. Cells were grown to near confluence in standard medium and then transferred and maintained for four additional days in serum-free Ham's F-10 medium. lodothyronines were added to the culture medium $4 \mathrm{~h}$ before harvesting. I5'D activity was determined using a $T_{4}$ concentration of $50 \mathrm{nM}$ and $20 \mathrm{mM}$ DTT. Points represent the mean of triplicate determinations, which differed $<5 \%$.

The regulatory effect of $\mathrm{rT}_{3}$ on $\mathrm{I}^{\prime} \mathrm{D}$ activity was shown to be quite rapid (Fig. 4). Significant inhibition was noted within 15 min of adding $\mathrm{rT}_{3}$ to the medium and was near maximal at $2 \mathrm{~h}$. A similar time course of inhibition was shown for $T_{4}$.

\section{Discussion}

I5'D activity in $\mathrm{GH}_{3}$ cells was shown in the present studies to be a thiol-dependent process with nonlinear reaction kinetics suggesting the presence of two enzymatic pathways having markedly different $K_{\mathrm{m}}$ values for $\mathrm{T}_{4}$. A differential sensitivity of these two processes to the inhibitory effects of PTU was also noted. These findings are similar to those previously described in homogenates of rat anterior pituitary glands (9, 13) and cerebral cortex (14). Our findings differ, however, from a prior report using $\mathrm{GH}_{3}$ cells where only a high $K_{\mathrm{m}}$ process $(3.8 \mu \mathrm{M})$ was identified (15). The failure to detect a low $K_{\mathrm{m}}$ process in this latter study may have been secondary to the low concentrations of DTT used $(2 \mathrm{mM})$ and the relative insensitivity of the $T_{3}$ RIA $(3.75 \mathrm{pg} /$ tube lower limits of detection vs. $0.2 \mathrm{pg} /$ tube in the present studies $[8,9])$.

Recent studies have shown that low $K_{\mathrm{m}}$ I5'D activity is

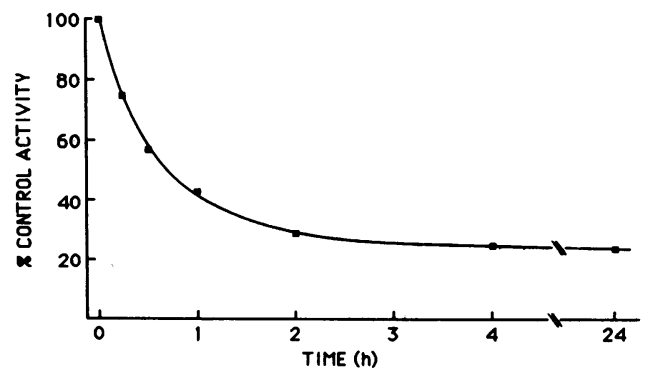

Figure 4. Time course of the inhibitory effect of $10^{-8} \mathrm{M} \mathrm{rT}_{3}$ on I5'D activity in $\mathbf{G H}_{3}$ cells. Cells were grown to near confluence in standard medium and then transferred and maintained in medium containing $10 \%$ resin-treated FCS. The $\mathrm{rT}_{3}$ was added to the culture medium before harvesting at the times indicated. I5'D activity was determined using a $\mathrm{T}_{4}$ concentration of $50 \mathrm{nM}$ and $20 \mathrm{mM}$ DTT. Points represent the mean of triplicate determinations, which differed $<5 \%$. responsible for the vast majority of "local" $T_{3}$ formation in the pituitary and depends on thyroid hormone status $(8,13)$. In hypothyroid animals, the activity of this process is markedly elevated, whereas thyroid hormone administration induces a rapid decrease in $T_{4}$ to $T_{3}$ conversion. Our finding that low $K_{\mathrm{m}}$ I5'D activity in $\mathrm{GH}_{3}$ cells rapidly responds to medium thyroid hormone concentrations supports the use of this cell line as a model system.

The effects of thyroid hormones on I5'D activity in various tissues are complex (16). In liver and kidney homogenates, $\mathrm{rT}_{3}$ inhibits $T_{3}$ formation by substrate competition with $T_{4}$ for a high $K_{\mathrm{m}}$ (type I) I5'D process (17). The suppressive effects of thyroid hormones on low $K_{\mathrm{m}}$ (type II) I5'D activity in $\mathbf{G H}_{3}$ cells, however, cannot be attributed to this mechanism. Our demonstration that $\mathrm{rT}_{3}$ is a potent inhibitor of this process contrasts sharply with the weak agonist activity of this analogue on other metabolic processes $(2,5)$ and strongly suggests that a unique regulatory mechanism, independent of the nuclear $T_{3}$ receptor, is responsible for this effect. Further evidence for this is the finding that relatively high concentrations of $T_{3}$ $\left(10^{-9} \mathrm{M}\right.$ in medium containing serum), which have been shown by other investigators to stimulate significantly growth hormone production and maximally suppress thyrotropinreleasing hormone receptors in $\mathrm{GH}_{3}$ cells (18), had no effect on I5'D activity. A recent report (19) demonstrating that the injection of $T_{4}$ or $\mathrm{rT}_{3}$ in the rat is more effective than $T_{3}$ in inhibiting pituitary and cerebral cortex $15 \mathrm{D}$ activity, suggests that the order of iodothyronine potency found in $\mathrm{GH}_{3}$ cells is also applicable in vivo. The cellular processes responsible for these regulatory effects are uncertain. Leonard et al. (20), however, have recently suggested that the $T_{3}$-dependent inhibition of $15^{\prime} \mathrm{D}$ activity in rat pituitary and cerebral cortex is mediated by a posttranscriptional mechanism that increases the rate of degradation or inactivation of the enzyme.

To date, a 5-deiodinase process has not been described in pituitary tissue and none could be demonstrated in the present study in $\mathrm{GH}_{3}$ cells when $\mathrm{T}_{3}$ was used as a substrate. This finding, together with the near equal potency of $\mathrm{T}_{4}$ with $\mathrm{rT}_{3}$, suggests that the regulatory effects of $T_{4}$ on $15^{\prime} \mathrm{D}$ activity are direct and not mediated by conversion to $\mathrm{rT}_{3}$.

An intriguing question raised by these studies is the possible role of $\mathrm{rT}_{3}$ in the control of $\mathrm{T}_{4}$ to $\mathrm{T}_{3}$ conversion in the pituitary and brain. Although $\mathrm{rT}_{3}$ appears to be a potent regulator of this metabolic process, its free concentration in normal human serum is $\sim 40$-fold lower than that of $T_{4}(21)$. Thus, $T_{4}$ rather than $\mathrm{rT}_{3}$ is likely to exert the principle physiologic control over this process. This thesis is consistent with reports that the administration of $\mathrm{rT}_{3}$ to normal human subjects has no effect on the serum levels of $T_{4}, T_{3}$, thyrotropin, or the thyrotropin response to thyrotropin-releasing hormone $(22,23)$. In nonthyroidal illness, however, marked alterations occur in thyroid hormone metabolism, which may result in decreased serum free $T_{4}$ levels and increases in serum free $r T_{3}$ levels of up to 15-fold (21). Under such circumstances, inhibitory effects of $\mathrm{rT}_{3}$ on $\mathrm{I}^{\prime} \mathrm{D}$ activity may become significant.

\section{Acknowledgments}

The author would like to thank Dr. P. Reed Larsen for the generous gift of the $T_{3}$ and $T_{4}$ antiserum, Dr. Valerie Anne Galton and Dr. Lee A. Witters for support and advice, and Ms. Roberta McLain for technical assistance. 
This research was supported by the National Institutes of Health Biomedical Support grant 2-SO7 RR 05392-22 and a grant from the Hitchcock Foundation (Hanover, NH). The author is the recipient of a Clinical Investigator Award (AM-01389).

\section{References}

1. Oppenheimer, J. H. 1979. Thyroid hormone action at the cellular level. Science (Wash. DC). 203:971-979.

2. Samuels, H. H., J. S. Tsai, and R. Cintron. 1973. Thyroid hormone action: a cell-culture system responsive to physiologic concentrations of thyroid hormones. Science (Wash. DC). 181:1253-1256.

3. Samuels, H. H., F. Stanley, and J. Casanova. 1979. Relationship of receptor affinity to the modulation of thyroid hormone nuclear receptor levels and growth hormone synthesis by L-triiodothyronine and iodothyronine analogues in cultured $\mathrm{GH}_{1}$ cells. J. Clin. Invest. 63: 1229-1240.

4. Surks, M. I., E. C. Fels, and C. R. DeFesi. 1984. Induction of amino acid transport by L-triiodothyronine in cultured growth hormoneproducing rat pituitary tumor cells (GC cells). J. Biol. Chem. 259: 5726-5733.

5. Papavasiliou, S. S., J. A. Martial, K. R. Latham, and J. D. Baxter. 1977. Thyroid hormonelike actions of 3,3',5'-L-triiodothyronine and 3,3'-diiodothyronine. J. Clin. Invest. 60:1230-1239.

6. Larsen, P. R. 1972. Direct radioimmunoassay of triiodothyronine in human serum. J. Clin. Invest. 52:1939-1949.

7. Samuels, H. H., F. Stanley, and J. Casanova. 1979. Depletion of L-3,5,3'-triiodothyronine and L-thyroxine in euthyroid calf serum for use in cell culture studies of the action of thyroid hormone. Endocrinology. 105:80-85.

8. St. Germain, D. L., and V. A. Galton. 1985. Comparative study of pituitary-thyroid hormone economy in fasting and hypothyroid rats. J. Clin. Invest. 75:679-688.

9. St. Germain, D. L., R. A. Adler, and V. A. Galton. 1985. Thyroxine 5'-deiodinase activity in anterior pituitary glands transplanted under the renal capsule in the rat. Endocrinology. 117:55-63.

10. Lowry, O. H., N. J. Rosebrough, A. L. Farr, and R. J. Randall. 1951. Protein measurement with the Folin phenol reagent. J. Biol. Chem. 193:265-275.

11. Galton, V. A. 1980. Binding of thyroid hormones in serum and liver cytosol of Rana catesbeiana tadpoles. Endocrinology. 107: 61-69.
12. Tashjian, A. H., Jr. 1979. Clonal strains of hormone producing pituitary cells. Methods Enzymol. 58:527-535.

13. Visser, T. J., M. M. Kaplan, J. L. Leonard, and P. R. Larsen. 1983. Evidence for two pathways of iodothyronine 5 -diodination in rat pituitary that differ in kinetics, propylthiouracil sensitivity, and response to hypothyroidism. J. Clin. Invest. 71:992-1002.

14. Visser, T. J., J. L. Leonard, M. M. Kaplan, and P. R. Larsen. 1982. Kinetic evidence suggesting two mechanisms for iodothyronine 5 '-deiodination in rat cerebral cortex. Proc. Natl. Acad. Sci. USA. 79: 5080-5084.

15. Melmed, S., M. Nelson, N. Kaplowitz, T. Yamada, and J. Hershman. 1981. Glutathione-dependent thyroxine 5'-monodeiodination modulates growth hormone production by cultured nonthyrotropic rat pituitary cells. Endocrinology. 108:970-976.

16. Larsen, P. R., J. E. Silva, and M. M. Kaplan. 1981. Relationship between circulating and intracellular thyroid hormones: physiologic and clinical implications. Endo. Reviews. 2:87-102.

17. Chopra, I. J. 1977. A study of extrathyroidal conversion of thyroxine $\left(T_{4}\right)$ to $3,3^{\prime}, 5$-triiodothyronine $\left(T_{3}\right)$ in vitro. Endocrinology. 101:453-463.

18. Hinkle, P. M., M. H. Perrone, and T. L. Greer. 1979. Thyroid hormone action in pituitary cells: differences in the regulation of thyrotropin-releasing hormone receptors and growth hormone synthesis. J. Biol. Chem. 254:3907-3911.

19. Silva, J. E., and J. L. Leonard. 1985. Regulation of rat cerebrocortical and adenohypophyseal type II 5 -deiodinase by thyroxine, triiodothyronine, and reverse triiodothyronine. Endocrinology. 116: 1627-1635.

20. Leonard, J. L., J. E. Silva, M. M. Kaplan, S. A. Mellen, T. J. Visser, and P. R. Larsen. 1984. Acute posttranscriptional regulation of cerebrocortical and pituitary iodothyronine 5'-deiodinases by thyroid hormone. Endocrinology. 114:998-1004.

21. Kaptein, E. H., W. J. Robinson, D. A. Grieb, and J. T. Nicoloff. 1982. Peripheral serum thyroxine, triiodothyronine, and reverse triiodothyronine kinetics in the low thyroxine state of nonthyroidal illness: a noncompartmental analysis. J. Clin. Invest. 69:526535.

22. Nicod, P., A. Burger, G. Strauch, A. G. Vagenakis, and L. E. Braverman. 1976. The failure of physiologic doses of reverse $T_{3}$ to effect thyroid-pituitary function in man. J. Clin. Endocrinol. Metab. 43:478-481.

23. Shulkin, B. L., and R. D. Utiger. 1984. Reverse triiodothyronine does not alter pituitary-thyroid function in normal subjects. J. Clin. Endocrinol. Metab. 58:1184-1187. 